\title{
O elemento islâmico na história e cultura afro-brasileira: referências para a promoção da lei $\mathbf{n}^{\mathbf{0}} \mathbf{1 0 . 6 3 9 / 0 3}$
}

\author{
Vilma Aparecida de Pinho* \\ Léia Gonçalves de Freitas** \\ Maurício Neubson Medeiros Gonçalves ${ }^{* * *}$ \\ Valter Luciano Gonçalves Villar****
}

\begin{abstract}
Resumo
Esta pesquisa teve como objetivo desenvolver um guia de referência sobre o elemento islâmico na cultura africanobrasileira como ferramenta de ensino no estudo da História e Cultura Afro-Brasileira na aplicação didática da Lei $\mathrm{n}^{\circ}$ 10.639/03.Esta é uma pesquisa teórica de abordagem qualitativa e de natureza bibliográfica, que disponibiliza dados e fontes que servem como suporte pedagógico para a análise da influência e contribuição de muçulmanos negros na história e na cultura africano-brasileira.
\end{abstract}

Palavras-Chave: Negros muçulmanos; Lei n 10.639/03; Interculturalismo.

\section{Islamic Element in the afro-brazilian history and culture: references for the promotion of the law $n^{0} .10 .639 / 03$}

\begin{abstract}
This research aimed to develop a reference guide on the islamic element in the african-brazilian culture as a teaching tool in the study of History and Afro-Brazilian Culture on the didactic application of the Law 10.639 / 03. This is a theoretical research of qualitative approach and bibliographic nature, which provide data and sources that serve as pedagogical support for the analysis of the influence and contribution of black Muslims in the history and african-brazilian culture.

Keywords: Black Muslims; Law 10.639/03; Interculturalism.
\end{abstract}

\section{Problematização da questão}

Esta pesquisa busca conhecer um pouco mais sobre os estudos da História e Cultura AfroBrasileira e Africana, especificamente as matrizes africanas islamizadas, além de procurar entender as referências históricas do islã no Brasil, intimamente relacionadas à História Negra e Africana e sua diáspora, que se quer são citadas nos currículos escolares.

Esta relação entre a religiosidade negra e a cultura islâmica necessita ser mais explorada pelos educadores que pretendem promover a interculturalidade no currículo escolar e combater o racismo e a intolerância em sala de aula. A Lei Federal $n^{\circ} 10.639 / 2003$ exige que o professor opere ativamente contra os males causados pelo racismo, etnocentrismo e intolerância religiosa. Contudo, sabe-se que uma formação continuada sobre o tema é praticamente inexistente e encontrar fontes e recursos disponíveis, acessíveis, não é tarefa fácil para os educadores, principalmente diante da miscelânea de textos, sem esmero, sobre o assunto.

Este trabalho, portanto, objetiva contribuir

*Endereço eletrônico: vilmaaparecidadepinho@ gmail.com

** Endereço eletrônico: leiafreitas@ufpa.br

**** Endereço eletrônico: mauricio.goncalves@ifpa.edu.br

**** Endereço eletrônico: valtervillar@gmail.com com o professor-pesquisador, em especial no tocante à seleção de referenciais sobre a religiosidade muçulmana que atendam à Lei $n^{\circ} 10.639 / 03$ além de outros conteúdos programáticos que abordem valores civilizatórios islâmicos. Ao se tornar obrigatório pela Lei Federal no 10.639, de 2003, o Ensino da História e Cultura Afro-Brasileira e Africana representa um marco legal no combate ao racismo e à intolerância no universo escolar brasileiro. Consequentemente, abrem-se caminhos para as discussões da religiosidade e dos valores civilizatórios, presentes nessas comunidades.

\section{A África islâmica: breve introdução}

O Alcorão, livro que compila as revelações do profeta em seus 23 anos de ministério, é o propulsor do processo de islamização dos povos árabes, tratando assuntos da vida pública e privada, profecias e leis civis. Em língua portuguesa, dispomos de algumas traduções do Alcorão, sendo as mais populares: O Alcorão-O Livro Sagrado do Islã de Mansour Chalita; a Tradução do significado do Alcorão Sagrado para a Língua Portuguesa de 
Samir El Hayek e a Tradução para a Língua Portuguesa do Sentido do Nobre Alcorão de Helmi Nars.

Nos primórdios da história islâmica, têm-se registrado relações étnico-raciais mais fraternas entre os primeiros muçulmanos. Dentre os primeiros seguidores do Profeta Muhammad, encontrava-se um escravo etíope (da Abissínia), chamado Bilal, que ao demonstrar simpatia pela mensagem libertária e igualitária do Islã ${ }^{\mathbf{1}}$, foi detido, torturado e quase morto pelo seu dono, até que foi comprado pelo companheiro de Muhammad, o Abu Bakr, alforriando-o logo em seguida. Bilal posteriormente foi nomeado como o primeiro Muezim (Almuadem) ${ }^{2}$.

Com o advento do Alcorão e da Lei Islâmica, algumas práticas da escravidão vigente da época préislâmica foram abolidas e outras restringidas, concedendo-se novos direitos aos servos e impondo condições e limites, acarretando a mudança da ordem social no tratamento aos cativos escravizados. Com o passar do tempo na sociedade muçulmana, a jurisprudência islâmica se encarregou de implementar e reinterpretar diversas posições em relação ao escravismo não explícitas no livro sagrado, retomando práticas que já tinham sido reformadas por Muhammad.

Não prejudiquem uns aos outros para que ninguém os prejudique. (...) Não devem infligir nem sofrer qualquer injustiça. (...) Toda a humanidade descende de Adão e Eva. Um árabe não é superior a um nãoárabe, nem um não-árabe tem qualquer superioridade sobre um árabe; o branco não tem superioridade sobre o negro, nem o negro é superior ao branco; ninguém é superior, exceto pela piedade e boas ações. Aprendam que todo muçulmano é irmão de todo muçulmano e que os muçulmanos constituem uma irmandade (MUHAMMAD, apud CAMPANI, 2015, p. 36).

Os povos africanos, ao fazerem contato e intercâmbio com a civilização islâmica, foram assimilando a língua árabe e seus produtos culturais. Dentre os Impérios e Reinos já existentes no continente africano, este processo intercultural esteve presente no Império Gana (750-1240), Império de Mali (1230-1546), Songai (1375-1591), Império de Benin (1440-1897), Império Ashanti (1670-1902), Impérios Kanem (700-1376) e Kanem-
Bornu (1387-1893), Império dos Almorávidas (1040-1146), Império Wolof (1360-1890); Reino de Gabu (1537-1867), Reino de Daomé (1625-1900), Reino de Oyo (1400-1905); Povos Iorubás, Povos Suaílis, Povo Haussá, Povo Etíope, Povo Núbio, Povo Afares, Povo Balantas; e, por fim, os Berberes e as cidades de "Sofala, Moçambique, Zanzibar, além de outras cidades-estados que estavam na fronteira do mundo islâmico. Eram cidades integradas às rotas comerciais do oceano índico, controladas pelos muçulmanos". (ALBUQUERQUE, 2006 p. 33).

\section{O Interculturalismo e a legislação brasileira}

A tese do Interculturalismo deste trabalho baseia-se nas concepções teóricas da educadora Vera Maria Candau, pois parte do entendimento de que as relações e o diálogo intercultural entre nossa sociedade e valores afro-islâmicos, ajudam na resolução da problemática da visão pejorativa sobre o "ser muçulmano", contido no imaginário social brasileiro e na escola. Os muçulmanos são geralmente indivíduos associados ao tom de ameaça e perigo, estereótipos negativos e imagens depreciativas, que reiteram, quase sempre, os epítetos de "bárbaro" e "terrorista". Esse discurso, forjado e modelado, como afirma Eduard Said ${ }^{3}$ (VILLAR, 2012), pelos meios de comunicação euroamericanos, tem como finalidade criar uma escala de terror, onde as políticas beligerantes encontram aceitação, tanto pelo público doméstico, quanto por outras comunidades ocidentais, no caso o Brasil.

Para superarmos essa visão homogênea, imprópria e excludente, é preciso entender o alcance dessas marcas e seus múltiplos efeitos no nosso sistema educacional, seus componentes interacionistas, a fim de encontrarmos os melhores planos e métodos que possam superar essa visão redutora, conforme se vê na afirmação abaixo:

Um enfoque que afeta a educação em todas as suas dimensões, favorecendo uma dinâmica de crítica, e autocrítica, valorizando a interação e comunicação recíprocas, entre os diferentes sujeitos, grupos culturais. A Interculturalidade orienta processos que têm por base o reconhecimento do direito à diferença e a luta contra todas as formas de discriminação $e$ desigualdade social. Tenta promover relações dialógicas e igualitárias entre pessoas e grupos que pertencem a universos diferentes, trabalhando conflitos inerentes a 
esta realidade. Não ignora as relações de poder presentes nas relações sociais $e$ interpessoais. Reconhece e assume os conflitos procurando as estratégias mais adequadas para enfrenta-los. (CANDAU, 2003. p. 19).

Esta proposta intercultural de orientação curricular da prática pedagógica corrobora com a pretensão do Parecer N. ${ }^{\circ}$ 003/2004- CNE/CP que institui as Diretrizes Curriculares Nacionais para a Educação das Relações Étnico-Raciais e para o Ensino de História e Cultura Afro-Brasileira e Africana. Um dos objetivos deste parecer prescreve ao educador, abordar "a história da ancestralidade e religiosidade africana" (p. 12), que por meio do Plano Nacional de Implementação destas diretrizes, de 2010 , incentiva a produzir materiais didáticos que "atendam e valorizem as especificidades (artísticas, culturais e religiosas) locais/regionais da população e do ambiente, visando ao ensino e à aprendizagem das Relações Étnico-raciais” (p. 32, 34).

Abordar o tema dos valores civilizatórios, seja na sociedade brasileira ou em qualquer outra sociedade com características pluriculturais semelhantes, não é tarefa de pouca dificuldade, sobretudo quando nos ocupamos em identificar seus conteúdos e significados amplos a partir de um referencial circunscrito a um universo cultural, por definição de pouca precisão, no caso que nos interessa, o universo cultural afro-brasileiro. Sendo assim, antes mesmo de propormos formas de introduzir os valores civilizatórios afro-brasileiros na elaboração dos currículos escolares, convém especificarmos, ainda que brevemente, qual a nossa compreensão do tema e, sobretudo, deixar clara a posição teórica que referencia essa nossa compreensão (MATTOS, apud RAMOS. 2003, p. 29).

Estas relações interculturais, decorrentes da confluência de povos africanos islamizados com outras etnias no Brasil, proporcionaram relações étnico-raciais positivas e, neste contexto, abordar a religiosidade islâmica no Ensino de História Cultura e Afro-Brasileira já é um grande passo para desmitificar os conflitos etnocêntricos e de intolerância religiosa em pauta na atualidade, pois "implica (...) em promover o diálogo e a troca entre diferentes grupos, cuja identidade cultural e dos indivíduos que os constituem são abertas e estão em permanente movimento de construção, decorrentes dos intensos processos de hibridização cultural" (CANDAU; KOFF, 2006, p. 102).

As mais recentes alterações da Lei de Diretrizes e Bases da Educação Nacional (LDBEN Lei $\mathrm{n}^{\circ} 9393$ de 1996), no seu artigo 26, parágrafo $4^{\circ}$, dispõem que: "O ensino da História do Brasil levará em conta as contribuições das diferentes culturas e etnias para a formação do povo brasileiro, especialmente das matrizes indígena, africana $\mathrm{e}$ europeia" (BRASIL, 1996), e no artigo 26A, parágrafos $1^{\circ}$ e $2^{\circ}$, recentemente alterados pela Lei $n^{\circ}$ $11.645 / 2008$, estabelece que:

$\S 1^{o}$ - "Nos estabelecimentos de ensino fundamental e de ensino médio, públicos e privados, torna-se obrigatório o estudo da história e cultura afro-brasileira e indígena. O conteúdo programático a que se refere este artigo incluirá diversos aspectos da história e da cultura que caracterizam a formação da população brasileira, a partir desses dois grupos étnicos, tais como o estudo da história da África e dos africanos, a luta dos negros e dos povos indígenas no Brasil, a cultura negra e indígena brasileira e o negro e o índio na formação da sociedade nacional, resgatando as suas contribuições nas áreas social, econômica e política, pertinentes à história do Brasil" (BRASIL, 2008, p. 1).

A problemática fundamental é que as abordagens publicadas sobre a cultura e religiosidade negra, antes da Lei $\mathrm{n}^{\circ} 10.639 / 03$, classificam e retratam os negros africanos simplesmente como Bantos e Sudaneses, que deram origem a religiões como o Candomblé, Quimbanda e Umbanda, etc. (OLIVA, 2003). Esta categorização é empobrecida e inadequada, pois se remete apenas aos grupos étnicos subsaarianos escravizados, como os Bantus e os Iorubás. Esta abordagem implica num currículo discriminatório, pois sucumbe toda a diversidade, tanto étnico-racial, quanto religiosa, dos grupos de toda a África, como salienta Gomes:

Práticas pedagógicas que se pretendem iguais para todos acabam sendo as mais discriminatórias. Essa afirmação pode parecer paradoxal, mas dependendo do discurso e da prática desenvolvida, pode-se 
incorrer no erro da homogeneização em detrimento do reconhecimento das diferenças (GOMES, 2000 apud CAVALLEIRO, 2010, p. 14).

\section{Fontes: caminhos abertos pela lei 10.639/03}

Os professores praticamente não dispõem de materiais didáticos a respeito dos negros muçulmanos, tampouco se capacitaram sobre as fontes que irão lhes fornecer sólidas bases teóricas para abordar o tema em sala de aula. As pesquisas sobre este tema são bem recentes, contudo há inúmeras publicações periódicas, acessíveis na Internet, que podem ser encontrados nas bibliotecas virtuais do Centro de Estudos Afro-Orientais (CEAO), em Salvador; do Centro de Estudos AfroAsiáticos (CEAA), no Rio de Janeiro; na revista AfroÁsia, da Universidade Federal da Bahia (UFBA); na revista Estudos Afro-Asiáticos, da Universidade Candido Mendes.

Os pesquisadores ainda dispõem da biblioteca virtual do Instituto de pesquisa Casa das Áfricas de São Paulo e dos textos publicados no portal Scielo e no Portal de Periódicos da Capes. Na perspectiva didático-pedagógica em termos de religiosidade e africanidade, o Ministério da Educação lançou as Contribuições para a Implementação da Lei 10.639/2003; Orientações e Ações para a Educação das Relações Étnico-Raciais e Educação Anti-Racista: Caminhos Abertos pela Lei Federal 10.639/03, além do Plano Nacional de Implementação das Diretrizes Curriculares Nacionais para Educação das Relações Etnicorraciais e para o Ensino de História e Cultura Afro-brasileira e Africana.

A Organização das Nações Unidas para Educação, Cultura e Ciência (UNESCO) também publica materiais, onde há referências aos negros africanos islamizados como o livro História $e$ Cultura Afro-Brasileira de Regina Augusto Mattos. O terceiro volume da coleção composta por oito livros, da História Geral da África (HGA) é quase todo dedicado ao processo de islamização da África, ocorrido a partir do século VII. Este material resultou na elaboração de um guia pedagógico dedicado aos professores da educação infantil, intitulado História e cultura africana e afro-brasileira na educação infantil.

O processo da educação básica dispõe, portanto, de fontes confiáveis que possibilitem um mapeamento da historicidade da presença islâmica na África e no Brasil e, neste contexto, este ensaio é exploratório, pois consiste em "levantar informações sobre um determinado objeto, delimitando assim um campo de trabalho, mapeando as condições de manifestação deste objeto" (SEVERINO, 2007, p. 123). Esta exploração limita-se ao recorte temporal da presença de elementos islâmicos no Brasil via África, pois este processo de interculturalismo histórico de etnias africanas de religião muçulmana, amparado pela Lei n ${ }^{\circ} 10.639 / 03$, é passível de análise pedagógica.

A especificidade do elemento islâmico na história do Negro no Brasil precisa ser considerada, explorada e discutida, haja vista que tiveram uma trajetória singular e constituíram uma categoria distintiva de grupos e etnias africanas. No livro Uma História do Negro no Brasil, os educadores podem encontrar muitas referências sobre grupos islamizados que vieram para o Brasil como escravos (diáspora afro-muçulmana), entre eles, os Fula, Mandinga, Haussás (Nagôs) e Tapas (Nupes), Bornos (ALBUQUERQUE, 2006), que foram representantes negros da tradição escrita dos escravos arabizados (DOBRONRAVIN, 2004). Os muçulmanos foram alvo de atenção dos primeiros estudos sobre os africanos, conforme se vê em Nina Rodrigues:

Através desse estudo [Os Africanos no Brasil], o autor queria fundamentar sua crença na diferença entre negros sudaneses $e$ bantos, conferindo por exemplo, um capítulo aos haussás (negros islamizados), que pertenciam ao tronco dos sudaneses, que, segundo o autor, seriam mais evoluídos que os outros africanos. Sobre as diferenças entre os negros, Rodrigues cita: "Aqui introduziu o tráfico poucos negros dos mais adiantados e mais do que isso mestiços camitas $^{4}$ convertidos ao islamismo $e$ provenientes de Estados africanos bárbaros, sim, porém mais adiantados. (RODRIGUES apud SOUZA, 1984, p. 4).

Atualmente, em toda África, os muçulmanos compõem $45 \%$ da população e estão concentrados em países como Egito, Nigéria, Etiópia, Marrocos, Argélia e Sudão. No Brasil, apesar do censo do IBGE de 2010 demonstrar que cerca 35.167 pessoas foram declaradas muçulmanas, entidades islâmicas especulam uma comunidade de cerca de um milhão e meio de pessoas, decorrentes, principalmente, de imigrantes de países islâmicos ${ }^{6}$.

É fundamental que os educadores 
compreendam, portanto, que os africanos para cá trazidos não tinham apenas como religiosidade o culto iorubano aos Orixás. Devem conscientizar-se ainda que os negros islamizados também mantiveram suas práticas e tradições, muitas delas em segredo, apesar dos numerosos adeptos:

Para o Brasil vieram também africanos iniciados em religiões que surgiram na África depois da chegada de povos árabes e europeus. Uma delas é o islamismo, introduzido por populações do norte do continente africano ao longo do multissecular comércio com os árabes. Os muçulmanos constituíram uma proporção pequena da população do Rio de Janeiro, mas eram numerosos na cidade de Salvador e na região açucareira do Recôncavo Baiano (ALBUQUERQUE, 2006, p. 105).

A Interculturalidade em religiosidades de matriz africana tem proporcionado um sincretismo de múltiplos elementos, tanto na África, como no Brasil. O documentário Atlântico Negro - A Rota dos Orixás $^{7}$ de 1998 e o livro Um rio chamado Atlântico: A África no Brasil e o Brasil na África de 2011 do autor Alberto da Costa e Silva marcam bem estes diálogos interculturais.

Assim também toda sociedade é, em alguma medida, intercultural, ou seja, essas culturas se misturam, intercambiam, sincretizam, $e$ não apenas superpõe-se, formando uma nova cultura. A diferença é de grau, nas sociedades multiculturais as culturas em contato tendem mais a superporem-se enquanto que nas sociedades interculturais as culturas tendem a imbricarem-se. (FONSECA, 2012, p. 97).

Os povos Iorubanos, tanto no Brasil como na África, foram influenciados por elementos islâmicos em muitos ritos aos Orixás, pois segundo Albuquerque (2006, p. 105), "entre os iorubás havia um grande número de muçulmanos, embora a grande maioria fosse devota de orixás". Talvez o elemento mais notável deste sincretismo e interculturalismo seja o uso ritual da indumentária do Abadá branco, presente no nosso Candomblé, influência da simbologia de pureza islâmica.

Há documentários, acessíveis a qualquer cidadão, que exploram o renascimento oriental, época denominada "Império da Razão", entre eles,
Quando os Mouros ${ }^{7}$ Dominavam a Europa ${ }^{8}, A$ Ciência e o Isla $\tilde{a}^{9}$, a série do History Channel "Humanidade: a História de Todos Nós" ${ }^{, 10}$ Episódio 4 - Guerreiros. Jonathan Lyons, autor do livro " $A$ Casa de Sabedoria”, relata como os árabesmuçulmanos salvaram a civilização ocidental e influenciaram a chamada "Era da Razão" dos Iluministas. A História Islâmica tem registrado volumosas e suntuosas bibliotecas. Foi lá também que se fundou, no norte da África, por uma mulher, muçulmana, de nome Fátima al-Fihri, a primeira Universidade moderna do mundo.

A presença islâmica do Brasil inicia-se, primeiramente, pelos mouros que por aqui passaram como viajantes marítimos, exploradores, comerciários ou fugitivos de perseguição religiosa da Inquisição; e depois pela vinda de negros africanos, escravizados, da qual se encontram mais registros, conforme se nota a seguir:

O marco desta diáspora muçulmana em Portugal é, sem dúvida, a tomada de Ceuta, em 1415, seguida da expedição a Tânger, em 1437, e sobretudo dos feitos de D. Afonso $V$, o Africano, com a tomada de Alcácer Ceguer, em 1458, Arzila e Tânger, em 1471, ano da fundação do Reino do Algarve de Além-Mar, marco institucional da presença portuguesa em África. Mais tarde, após a circunavegação da África, já no reinado de D. Manuel, Portugal chegaria à Índia, alargando para o oriente seu vasto império ultramarino. Da África, especialmente do Marrocos, vinham mercadorias diversas, negociadas nos portos de Safim e Azamor onde os portugueses estabeleceriam praças militares, como também o fariam em Mazagão. Da Índia, viriam as cobiçadas especiarias, no comércio garantido pela rede militar de Goa ou Diu. Mas tanto do Norte da África como do Oriente, viriam também escravos, em sua maioria muçulmanos, principal fonte dos mouriscos do reino, com destaque para os magrebinos (RIBAS, 2006, p. 02).

A diáspora islâmica para a América é intensificada pelas Bulas Papais Dum Diversas (1452) e Romanus Pontifices (1454) (Pires, 1988), que admitiam a captura e escravidão dos sarracenos, isto é, dos muçulmanos:

\section{[...] outorgamos por estes documentos}

Horizontes, v. 34, n. 1, p. 55-68, jan./jul. 2016 
presentes, com a nossa Autoridade Apostólica, permissão plena e livre para invadir, buscar, capturar e subjugar sarracenos e pagãos e outros infiéis $e$ inimigos de Cristo onde quer que se encontrem, assim como os seus reinos, ducados, condados, principados, e outros bens [...] e para reduzir as suas pessoas à escravidão perpétua (PIRES, 1988, p. 277).

Por certo que também havia comércio e tráfico negreiro no mundo árabe-islâmico ${ }^{11}$, mas as razões e circunstâncias da escravidão na América Portuguesa e na Europa não foram equivalentes. Ademais, cabe pressupor que desde o início da escravidão no Ocidente houve uma intenção de sanear e dirimir a influência e o domínio econômico e cultural dos muçulmanos na Europa e na África, marcando-os até hoje com os estigmas dos muçulmanos como piratas, bárbaros, hereges, pagãos e infiéis (VILLAR, 2012, p. 37).

Alguns acadêmicos (ARAÚJO, 2005; CASTRO, 2007; JERRAHI, 2003; SOUZA, L., 2004) têm reforçado o indício que Pedro Alvares Cabral teria recebido orientação de dois navegantes muçulmanos, por nomes de Chuhabidin Bin Májid e o Mussa Bin Sáte, ao desviar sua rota e "descobrir" o Brasil. De qualquer forma o processo de interculturalidade da religiosidade muçulmana foi mais significativo quando os negros africanos escravizados adentraram o país.

Destas relações interculturais, há o caso de um capitão mouro que teve passagem pelo Brasil no auge da escravidão do século XVII. No intuito de narrar sua saga, Georges Bourdoukan, autor do livro A Incrível e Fascinante História do Capitão Mouro, refaz sua história de forma épica, destacando suas relações com o Quilombo dos Palmares e Zumbi. O escritor conta que o muçulmano negro, ao sair para uma peregrinação para Meca, por via marítima, sofre um naufrágio, é aprisionado por piratas e depois de resgatado, fora levado para o Brasil, onde buscou encontrar um de seus irmãos, refugiado da Inquisição.

Enquanto isso, no Magreb, ocidente do mundo islâmico, havia um capitão mouro, Karim Ibn Ali Saifudin, que partiu do Saara marroquino em peregrinação a Meca. Tendo naufragado na costa africana, foi salvo por um judeu, Bem Suleiman, que iniciava uma viagem ao Brasil. Fizeram juntos a travessia do Atlântico e, uma vez em Pernambuco, adotou o nome português Inocêncio de Toledo. Após constatar a situação dos africanos escravizados e a existência dos "fujões", foi levado pelo amigo judeu a Palmares. $O$ que viu o envolveu no movimento palmarino e a ajuda de Saifudin na fortificação do quilombo seria conhecida pelo governador de Pernambuco, Caetano de Melo e Castro, que depois o referiria ao rei de Portugal (BOURDOUKAN, 2001, p. 29).

Nina Rodrigues, Etiènne Brasil, Arthur Ramos, Gilberto Freyre, João do Rio, Abelardo Duarte e Waldemar Valente (RIBEIRO, 2009, p. 288) foram alguns dos estudiosos que citaram a presença de negros muçulmanos no Brasil. Gilberto Freyre e Darcy Ribeiro, por sua vez, escreveram sobre a influência moura na construção da singularidade brasileira, herdada e transmitida pelos portugueses mestiços. Já Conde de Gobineau (18161882) e Nina Rodrigues (1862-1906), trataram sobre a islamização de povos africanos como fator de adiantamento civilizatório. Após uma de suas estadias no Brasil, numa correspondência datada de 1889, Gobineau assim descreve o Rio de Janeiro:

Simbá, o marujo, conseguindo chegar à margem do rio, avistou montanhas cobertas de bosques compactos e, no meio de um vale, uma bela e grande cidade cujos monumentos lhe parecem numerosos e imponentes. Ele se dirige até a cidade, e qual não é sua surpresa quando percebe que a multidão de gente, que de longe parecia povoar as ruas, era na verdade, uma multidão de macacos! Havia grandes e pequenos, novos e velhos; mas todos eram macacos extremamente feios, fazendo caretas atrozes e circulando de um lado para o outro, uns apressados, outros, não: tão lúgubres. Depois de muito andar a esmo de um lado para o outro. Simbá, enfim, ao alto de um bairro, onde avistou um grande palácio que julgou ser o rei deste povo: e, entretanto nos pátios onde os macacos que passavam nada fizeram para prendê-lo, penetrou nos apartamentos, e depois de atravessar várias galerias teve uma agradável surpresa, ao ouvir o som de uma voz humana: e de fato, dirigindo-se para o lado de onde vinha a voz, entrou numa sala e viu, finalmente, um homem! E este homem lia o Alcorão. De modo que não 
apenas encontrara um ser de sua espécie, mas um ser com que podia se entender. Suponho, madrinha, que com a aguda inteligência que a distingue... você adivinhou que Simbá estava no Brasil, que os macacos eram os brasileiros e que o rei era o Imperador (GOBINEAU apud READERS, 1988, p. 77-78).

O zoólogo Louis Agassiz (1807-1873), um dos notórios teóricos racialistas do século XIX, também faz um relato sobre o grupo muçulmano no Rio de Janeiro, durante sua expedição, na qual relata a filiação religiosa dos negros Minas: "Os homens desta raça são maometanos e conservam, segundo se diz, sua crença no profeta, no meio das práticas da Igreja Católica. Não me parecem tão afáveis e comunicativos como os negros congos: são, pelo contrário, bastante altivos" (AGASSIZ, 2000, p. 102).

No Brasil, os negros islamizados se diferiam dos negros de outras religiosidades principalmente pelos seus caracteres culturais. $\mathrm{O}$ antropólogo e etnologista Arthur Ramos distinguia os muçulmanos em sua obra pelos seus traços culturais: "Eram altos, robustos, fortes e trabalhadores. Usavam como os outros negros muçulmanos, um pequeno cavanhaque, de vida regular e austera, não se misturavam com os outros escravos." (JERRAHI, 2003, p.2)

A intensificação do tráfico de negros islamizados ocorreu nos séculos XVIII e XIX, com o início do ciclo do ouro mineiro no Brasil no século XVIII e com a rota de tráfico Costa de Mina e da Baía de Benin. Os negros islamizados foram espalhados por todo o território brasileiro, mas houve concentração maior na região do Recôncavo baiano, devido ao porto de Salvador ter sido um desembarque bem mais próximo das rotas escravocratas.

Cabe ressaltar que como a religião oficial do Brasil colonial e imperial era o catolicismo, não se admitia o ensino islâmico, ocorrendo que as práticas religiosas dos negros muçulmanos eram discretas e escondidas, nas quais utilizavam a privacidade de suas próprias casas como congregações e casas de adoração. O Islã da população negra no Brasil resistiu a todas as formas de sincretismo, inovação (modernização ocidental) e folclorização, o que favoreceu seu processo de desaparecimento, principalmente com o sufocamento das insurreições religiosas dos muçulmanos na Bahia.

\section{Revolta dos Malês}

A Revolta dos Malês, ocorrida em 1835, na cidade de Salvador, talvez seja o mais conhecido caso de resistência islâmica no Brasil, embora Haussás e Nagôs tenham se rebelado em mais de 30 tentativas de emancipação desde 1807 (REIS, 2014). Pierre Verger e Roger Bastide são alguns dos autores que comentaram sobre o papel da religião islâmica na organização da resistência contra a escravidão. Destaca-se ainda o extenso trabalho de João José Reis registrada no livro Rebelião Escrava no Brasil - A História do Levante dos Malês de 1835 e o livro de Nei Lopes Bantos, Malês e Identidade Negra.

Os malês foram os grandes promotores das revoltas e movimentos de libertação. Instruídos, com capacidade de organização, $e$ motivados pelos ideais islâmicos de liberdade e resistência à tirania, mobilizaram seus pares em diversas revoltas. O início do século XIX foi marcado por uma sequência de revoltas denunciando $o$ clima de tensão crescente $e \quad o$ inconformismo com a situação de escravidão. As principais ocorreram nos seguintes meses e anos: maio de 1807; 4 de janeiro de 1809; fevereiro de 1810; fevereiro de 1814; janeiro e fevereiro de 1816, junho e julho de 1822; agosto e dezembro de 1826, abril de 1827; março de 1828; abril de 1830. [...] Em 25 de janeiro de 1835 ... Os revoltosos percorreram as ruas da capital da Bahia, atacaram o palácio do Presidente da província, invadiram quartéis, enfrentaram tropas e fragatas de guerra ancoradas no porto. Foram totalmente subjugados pelas forças do governo. (ALJERRAHI, 2003, p. 3).

Os Malês, como eram chamados os muslins (muçulmanos) na Bahia, eram organizados e comprovariam, na prática, o quão temido eram pelos traficantes e donos de escravos. Segundo Reis (2003), cerca de 600 escravos e libertos participaram do motim e quase todos morreram. Os poucos que escaparam, foram presos ou deportados para a África. Os flagrantes revoltosos foram apreendidos com amuletos contento trechos do Alcorão escritos em árabe. Negros muçulmanos, a partir de então, que fossem flagrados com símbolos sagrados islâmicos ou escritos árabes, passariam a ser castigados, o que na prática resultou na proibição do islamismo.

Há um caso curioso registrado nos arquivos judiciais de Salvador, no qual um escravo nagô de 
nome R. Torquato, ao ser abordado com cópias manuscritas em árabe, foi acusado de participação na revolta e subversão, processado conforme a sentença:

\section{Conformando-me com a decisão dos Jurados condemno o R. Torquato, escravo de Jé Pinto Novais na pena de 250 açoites; o Escrevão o que o recommende na prizão, $e$ pague o Reo as custas, em q também o condemno, ou seu Senhor por elle. $13 .^{a} 9 \mathrm{Dz}{ }^{\circ}$ 1835. Caetano Vicente d'Almd ${ }^{a} \mathrm{Jr}$. (REICHERT, 2006, p. 21).}

Em meio à revolta, destaca-se o papel de uma mulher negra chamada Luiza Mahin, da tribo Mahi do povo Nagô, na qual sendo alforriada e fabricante de doces, enviava mensagens em árabe e as escondia dentro dos doces, para comunicação e organização dos articuladores das revoltas dos Malês. Luíza é a mãe do abolicionista Luís Gama, considerado um dos pioneiros do movimento do século XIX pela abolição, fato que lhe rendeu os epítetos de "maior abolicionista do Brasil" e "apóstolo negro da abolição".

Muitos dos muçulmanos negros no Brasil por saberem ler e escrever em árabe, mantiveram contato com outros grupos fora do país, no intuito de manterem preservada sua religião. Já no Rio de Janeiro, na mesma época, Alberto Costa e Silva (2004) tem destacado que no século XIX, havia grande demanda por alcorões:

No Dia 22 de setembro de 1869, o conde de Gobineau, na época ministro da França no Brasil, escreveu num relatório político para o Quai d'Orsay que os livreiros franceses Fauchon e Dupont costumavam vender todos os anos, em sua loja no Rio de Janeiro, quase cem exemplares do Alcorão. Embora muito caro (entre 36 e 50 francos franceses), o livro era comprado quase que exclusivamente por escravos e ex-escravos, que tinham de fazer grandes sacrificios para adquiri-lo. Alguns deles compravam o livro a prestação, e levavam um ano para pagá-lo (SILVA, 2004, p.1).

A tradição escrita dos negros muçulmanos sobressai entre os demais negros africanos, uma vez que relatos do olhar negro sobre a escravidão no Brasil veem de muçulmanos. Destaca-se o relato do líder religioso muçulmano, oriundo do Império Otomano, Abdel Rahman al Baghdadi, que morou no
Brasil por três anos, por volta de 1866. Por aqui, visitou Salvador, Recife e Rio de Janeiro, ensinando o Islã a pedido de escravos africanos. Ele próprio registrou esta passagem e a situação dos escravos no Brasil, num livro chamado Deleite do Estrangeiro em Tudo o que é Espantoso e Maravilhoso (PINHEIRO, 2010).

Outro destaque é um fascinante relato autobiográfico de um negro muçulmano de Benin, chamado Mahommah Gardo Baquaqua, que foi vendido como escravo em 1845 e viveu três anos no Brasil, até conseguir fugir para o EUA em 1847, onde se tornou missionário batista e escreveu sua biografia em 1854 (LARA, 2009; LOVEJOY, 2002).

A História do Brasil tem registrado muitas referências sobre líderes religiosos islâmicos entre os negros, conhecidos sob os títulos de Alufá (sacerdote), Sheik (líder), Imam (chefe, teólogo), Malam (erudito). Dentre os mais conhecidos estão o Alufá Rufino (de Recife), o Alufá Assumano Mina (do Rio de Janeiro), Alufá Julio Ganan (do Rio de Janeiro), Alufá Mama (Dassalu), Sheik Buremo (Gustard), Sheik Sule (Nikobé), Alufá Manoel Calafate, Imam Nagô Belchior, Alufá Bilal Licutan (Pacífico), Alufá Dandará, Alufá Sanin, Alufá Mama, Alufá Sule (RIBEIRO, 2009). Muitos deles utilizaram suas casas como os primeiros centros de oração congregacional e culto islâmico no Brasil.

A fase do Islã clandestino entre os negros no Brasil decai com o avanço do proselitismo protestante, porém é recuperado com a chegada de imigrantes muçulmanos e árabes, principalmente sírios e libaneses, no século $\mathrm{XX}$, nas quais culminaram no estabelecimento da primeira e mais antiga mesquita do Brasil em funcionamento, construída em 1929, na cidade de São Paulo. Atualmente existem mais de 100 mesquitas e centros islâmicos em todo território nacional, segundo a União de Entidades Islâmicas do Brasil. Na cidade de Belém, capital do Estado do Pará, em 2013, foi fundada a mesquita Ar-Rahmas, do ramo sunita, onde também funciona o Centro Islâmico Cultural do Pará. Ainda no Pará, a UFPA, por intermédio da PROINTER, oferece o curso de Língua Árabe, condição essencial para se ler o Alcorão. No estágio atual, o Islã tem adentrado cada vez mais nos centros periféricos das grandes cidades ${ }^{\mathbf{1 2}}$.

Ao correlacionar com a Lei $n^{\circ} 10.639 / 03$, o professor pode obter múltiplos contributos árabeislâmicos de negros africanos e imigrantes do oriente médio, para o trabalho pedagógico em sala de aula. $\mathrm{Na}$ arquitetura e urbanismo: a tradição do azulejo. $\mathrm{Na}$ música brasileira: a adoção da guitarra, violão e 
violino, rabeca, originados do alaúde e rebab, adoção do pandeiro (riq), do adufe, da flauta (nay), da zambumba de duas faces, dos címbalos, do atabaque. $\mathrm{Na}$ literatura, histórias e contos orientais como Aladin, (adaptado pela Disney), Alí Babá e os 40 ladrões, Simbá, o Marujo, contido nos contos de As Mil e Uma Noites, além de obras traduzidas de grandes poetas muçulmanos, entre eles, Rumi, Attar, Omar.

Atualmente, o Canal Futura tem transmitido o desenho Saladino, que dramatiza as aventuras da juventude do libertador de Jerusalém dos Cruzados. Esta animação é uma boa fonte de aprendizado infantil sobre a cultura árabe-islâmica. $\mathrm{O}$ uso do abadá branco usado em Rodas de Capoeira é uma boa forma de se introduzir a religiosidade afro-islâmica aos alunos, uma vez que a indumentária além de fazer parte da indumentária tradicional de rodas de Capoeira, é uma vestimenta ritual islâmica da Hajj (peregrinação), traje este também presente em ritos do Candomblé e no ofício das baianas do acarajé.

Enfim, o trabalho pedagógico do educador na abordagem da religiosidade islâmica do negro africano é delicado, mas exige um esforço de pesquisa do professor, uma vez que a herança muçulmana tem sido "esquecida" intencionalmente na História Ocidental. As fontes de referências potenciais tenderão a ser maiores, conforme vão se ampliando os estudos sobre os elementos islâmicos na sociedade brasileira.

\section{Considerações Finais}

O professor da educação básica dispõe de uma breve e concisa indicação de referenciais para a abordagem da religiosidade islâmica dos negros aqui escravizados. Esta pesquisa neste sentido é inacabada e incompleta, mas fica a cargo dos educadores o aprofundamento deste tema trabalhado. O simples ato de se aludir ou provocar a discussão sobre a cultura islâmica entre os negros africanos no Brasil já é um grande passo para se desconstruir séculos de preconceitos em relação à diversidade étnico-racial e cultural afro-brasileira.

Conscientizemo-nos que, no Brasil, os negros muçulmanos foram repreendidos não somente pelo fato de serem negros, mas também pelo fato de praticarem sua religião, numa época onde a intolerância e falta de liberdade religiosa era mais praticada. O que queremos demonstrar é que da mesma forma que houve e há um racismo institucional, também houve a intolerância religiosa institucional e os dois males na história afro- brasileira sempre estiveram interligados, isto é, o racismo e o preconceito religioso, no Brasil, caminharam juntos.

Os professores, ao lidarem com a história negra no Brasil, devem encontrar nestes referenciais uma melhor compreensão da importância da Lei ${ }^{\circ}$ $10.639 / 2003$, para abordagens da religiosidade de matriz africana. Embora o número de alunos negros muçulmanos matriculados no Brasil seja ínfimo e desconhecido, esta aquisição de conhecimento não diz respeito apenas ao tratamento do aluno muçulmano, mas sim serve de entendimento acerca do conflituoso complexo de valores civilizatórios entre essas comunidades.

Atualmente, a mídia brasileira tem destacado atitudes perversas e corruptas de fanáticos, extremistas, radicais, colocando-os, erroneamente, como representantes da religião islâmica, reforçando a ideia de que todo muçulmano é terrorista (o que teoricamente seria $20 \%$ da Humanidade), discurso este reproduzido na escola e que vai ao encontro do que propõem a Lei ${ }^{\circ} 10.639 / 03$, que é a investigação dos fatos e da realidade de forma imparcial. Os professores neste sentido têm de ser capazes de distinguir com nitidez o islamismo exógeno da mídia, como da novela o Clone e das manchetes dos Jornais, do islamismo promotor da paz, da justiça, da harmonia racial, da tolerância, da civilidade e da espiritualidade como o do atleta negro Jadel Gregório, convertido por livre investigação, por exemplo.

Este movimento de conscientização, que já vem sendo conquistado aos poucos por outras religiões de procedência africana, como o Candomblé, também repercute na Fé Islâmica, tem crescido nas periferias, principalmente entre mulheres e homens negros, pobres e integrantes do movimento Hip Hop, como mostra o documentário Os manos de Alá ${ }^{13}$.

Por fim, assim como determina a LDB, o estudo da história e cultura afro-brasileira e africana, principalmente nos campos da História, Literatura e Arte tem um forte potencial para o trabalho pedagógico, através da investigação do elemento e a influência islâmica em nossa diversidade étnicoracial. Os referenciais aqui apresentados podem ser trabalhados pelos professores na produção de material didático-pedagógico que atendam aos valores da unidade da diversidade, que é o melhor caminho para uma educação mais intercultural.

\section{Notas}

Horizontes, v. 34, n. 1, p. 55-68, jan./jul. 2016 
1 A mensagem de Muhammad ensinava que diante Referências de Allah não havia senhores nem escravos, mas que todos eram igualmente submissos e servos a Allah.

2 Muezim ou Almuadem é a pessoa que têm a função de anunciar o chamado para cada uma das cinco orações rituais diárias (salat) em voz alta em cima dos minaretes das mesquitas.

3 Eduard Said foi um escritor palestino e um dos mais notórios críticos dos conceitos ocidentais sobre o Oriente bárbaro. Sua obra prima é Orientalismo: $O$ Oriente como Invenção do Ocidente.

4 Pressupõe-se que o termo "camita" empregado por Nina Rodrigues seja uma referência do imaginário cristão medieval que associava os negros africanos como os descendentes dispersos de Cam, filho de Noé.

5 Dados da Federação Islâmica do Brasil segunda a revista Galileu. Disponível em: $<$ http://galileu.globo.com/edic/124/rep_dossie1.ht $\mathrm{m}>$. Acesso em: 13 de outubro de 2014.

6 Atlântico Negro - Na Rota dos Orixás. Disponível em: <https://www.youtube.com/watch? $\mathrm{v}=\mathrm{VyAebz}$ RS3h8>. Acesso em: 22 de outubro de 2014.

7 Mouro é o termo utilizado na Europa cristã para designar os muçulmanos, geralmente de pele morena.

8 Quando os Mouros Dominavam a Europa. Disponível em: <https://www.youtube.com/watch?v=Av0MCGVc BeM>. Acesso em: 23 de setembro de 2014.

9 A Ciência e o Islam. Disponível em: $<$ https://www.youtube.com/watch? $\mathrm{v}=$ ocsveagHeV 0>. Acesso em: 04 de setembro de 2014.

10 Humanidade: A História de Todos Nós - Episódio 4 - Guerreiros. History Channel. Disponível em: $<$ https://www.youtube.com/watch?v=5tunfl7b7Z w>. Acesso em: 07 de setembro de 2014.

11 A escravidão árabe-islâmica não teve as conotações raciais equivalentes as ocidentais, haja vista que negros muçulmanos também tinham escravos brancos e pertencentes a diversos povos e grupos étnicos e religiosos.

12 Islã cresce na periferia das cidades do Brasil. Disponível em: $<$ http://revistaepoca.globo.com/Revista/Epoca/0,,E RT25342-15228-25342-3934,00.html>. Acesso em: 09 de novembro de 2014.

13 Os Manos de Alá. Disponível em: <http://www.youtube.com/watch?v=LIcKfRhP4c U>. Acesso em 09 de novembro de 2014.
AGASSIZ, J. L. R. Viagem ao Brasil 1865-1866. Tradução e notas de Edgar Süssekind de Mendonça. - Brasília: Senado Federal, Conselho Editorial, 2000.

ALBUQUERQUE, W. R. de. Uma história do negro no Brasil. Salvador: Centro de Estudos AfroOrientais. Fundação Cultural Palmares. Brasília, 2006.

AL-JEHHARI, Muhammad Ragip. História da Presença Islâmica no Brasil. Palestra para o Congresso "El Islam em las dos Orillas" - Sevilha, $2003 . \quad$ Disponível em: <http://www.masnavi.org/jerrahi/Artigos__Palestr as/Historia_da_presenca_Islamica_/historia_da_pres enca_islamica_.html>. Acesso em: 13 de outubro de 2014.

ARAÚJO, E. J. S. Presença Islâmica no Nordeste Brasileiro. Monografia para a PUC-PE, Recife, 2005.

BOURDOUKAN, G. A Incrivel e Fascinante História do Capitão Mouro. 5. Ed. Casa Amarela, 2001.

BRASIL. Lei $\mathrm{n}^{\mathrm{a}} 11.645$ de 10 de março 2008. Disponível em <http://www.planalto.gov.br/ccivil_03/_ato2007-20 10/2008/lei/111645.htm>. Acesso em 10 de outubro de 2014.

BRASIL. LEI $N^{o}$ 10.639, DE 9 DE JANEIRO DE 2003. Brasília, 2003. Disponível em: << http://www.planalto.gov.br/ccivil_03/leis/2003/110. 639.htm>. Acesso em: 07 de setembro de 2014.

BRASIL. LEI $N^{\circ}$ 9.394, DE 20 DE DEZEMBRO DE 1996. Disponível em: < http://www.planalto.gov.br/ccivil_03/leis/19394.htm >. Brasília, 1996. Acesso em: 07 de setembro de 2014.

BRASIL. MEC/CNE. RESOLUÇÃO $N^{o} 1$, de 17 de junho 2004. CNE - MEC. Brasília, 2004.

BRASIL. Orientações e Ações para a Educação das Relações Étnico-Raciais.Brasília: SECAD, 2010.

BRASIL. Parecer N. ${ }^{\circ}: C N E / C P \quad 003 / 2004 \quad-$ 
Diretrizes Curriculares Nacionais para a Educação das Relações Étnico-Raciais e para o Ensino de História e Cultura Afro-Brasileira e Africana. Brasília, DF, 2004.

BRASIL. Plano Nacional de Implementação das Diretrizes Curriculares Nacionais para a Educação das Relações Étnico-Raciais e para o Ensino de História e Cultura Afro-Brasileira e Africana. Brasília, DF, 2010.

CANDAU, V. M., KOOF, A. M. N. S. e. Conversas com... Sobre a didática $e$ a perspectiva multi/intercultural. In CANDAU, Vera Maria. Educação Cultural e Cotidiano Escolar. Editora 7 Letras: Rio de Janeiro, 2006.

CANDAU, V. M. Relatório da Pesquisa Universidade, Diversidade Cultural e Formação de Professores. Rio de Janeiro: Departamento de Educação da PUC-RIO, 2003.

CAMPANI, C. A. P. Um Guia para o Islã. CreateSpace, 2015.

CASTRO, C. M. de. Muçulmanos no Brasil contemporâneo: considerações a respeito da suposta particularidade brasileira na recepção de imigrantes. CEBRAP. $31^{\circ}$ Encontro Anual da ANPOCS, Caxambu, MG, 2007.

DOBRONRAVIN, N. Escritos Multilíngues em Caracteres Árabes: novas fontes de Trinidad e Brasil no século XIX in Revista Afro-Ásia, 31 (2004), $297-$ 326.

FONSECA, D. R. As raízes do sincretismo religioso afro-brasileiro. Revista Língua Viva, GuajaráMirim/RO, Vol. 2, N. 1, p. 96-136, jul./dez. 2012. Disponível em: http://www.periodicos.unir.br/index.php/linguaviva/ article/download/567/665. Acesso em 08 de out 2014.

GOMES, N. L. Educação cidadã, etnia e raça: o trato pedagógico da diversidade. In: CAVALLEIRO, Eliane (org.). Racismo e anti-racismo na educação: repensando nossa escola. São Paulo: Selo Negro, 2000.

Educação, raça e gênero: relações imersas na alteridade. Cadernos Pagu (6-7) 1996: pp.67-82.
LARA, S. H. Biografia de Mahommah G. Baquaqua. Universidade Estadual de Campinas, 2009. Disponível em: <http://www.anpuh.org/arqui vo/download?ID_ARQUIVO=3686>. Acesso em: 08 de novembro de 2014.

LOPES, N. Bantos, Malês e Identidade Negra. Editora Autêntica. 2006.

LOVEJOY, P. E. Identidade e a miragem da etnicidade a jornada de Mahommah Gardo Baquaqua para as Américas. Revista Afro-Ásia. Disponível em: <http://www.afroasia.ufba.br/pdf/27_7_identidade.p df $>$. Acesso em: 13 de novembro de 2014.

LYONS, Jonathan. A Casa de Sabedoria: como a valorização do conhecimento pelos árabes transformou a civilização ocidental. (Trad. Pedro Maia Soares). Jorge Zahar: Rio de Janeiro, 2011.

MATTOS, R. A. História e Cultura Afro-Brasileira. Contexto, 2007.

MATTOS, W. R. de. Valores Civilizatórios AfroBrasileiros na Elaboração de Currículos Escolares - ensaiando pressupostos in RAMOS, Marise Nogueira (orga.) Diversidade na educação: Reflexões e Experiências. SETEC, Brasília, 2003.

PINHEIRO, C. C. Periferias históricas revisitadas. As leituras árabes-islâmicas de Al Baghdádi sobre o Brasil do século XIX. Estud. hist. (Rio J.) vol.23 no.45 Rio de Janeiro Jan./June 2010. Disponível em: <http://www.scielo.br/scielo.php?pid=S0103218620 $10000100011 \&$ script=sci_arttext $>$. Acesso em: 07 de outubro de 2014.

OLIVA, A. R. O Ensino da História da África em debate (uma introdução aos estudos africanos). Disponível em: http://repositorio.unb.br/bitstream/1 0482/6167/1/CAPITULO_EnsinoHist\%C3\%B3riaA frica.pdf Acesso em 08 de out 2014.

PIRES, J. M. A Igreja e a Escravidão no Brasil. Convergência. Revista da Conferência dos Religiosos do Brasil - CRB. Disponível em: http://crbnacional.org.br/acervo/1988/06-1988.

OCR.pdf. Acesso em 14 out 2016.

READERS, G. O inimigo cordial do Brasil: o Conde de Gobineau no Brasil. Trad. Rosa Freire Aguiar. São Paulo: Paz e Terra, 1988. P. 77-8. 
REICHERT, R. Os documentos árabes do Arquivo do Estado da Bahia. Estudos Afro-asiáticos. Edição 9. CEAO/UFBA. Salvador, 1979.

REIS, J. O sonho da Bahia muçulmana. Artigo da Revista de História. Disponível em: < http://www.revistadehistoria.com.br/secao/dossieimigracao-italiana/o-sonho-da-bahia-muculmana. Acesso em: 15 de outubro de 2014.

. Rebelião escrava no Brasil: a história do levante dos malês em 1835. Companhia das Letras, 2003.

RIBAS, R. O. Mouriscos Cavaleiros e Mouriscos de bens no Império Português. Disponível em: http://anais.anpuh.org/wp-content/uploads/mp/pdf/A NPUH.S25.1504.pdf. Acesso em 8 de out 2015.

- Negros islâmicos no Brasil escravocrata. USP. 2009.

SAID, E. Orientalismo: o Oriente como invenção do Ocidente. Tradução Tomás Rosa Bueno. São Paulo: Companhia das Letras, 1990.

SEVERINO, A. J. Metodologia do Trabalho Científico. 23. ed. Edit. Cortez. São Paulo, 2007.

SILVA, A. C. Comprando e vendendo Alcorões no Rio de Janeiro do século. XIX. Estudos Avançados. Vol. 18. n ${ }^{\circ}$ 50. São Paulo, 2004. Disponível em: <http://www.scielo.br/scielo.php?pid=S0103-40142 $004000100024 \&$ script $=$ sci_arttext $>$. Acesso em: 09 de outubro de 2014.

Um rio chamado Atlântico: A África no Brasil e o Brasil na África. Nova Fronteira: Rio de Janeiro, 2014.

SILVA, A. C. A Desconstrução da Discriminação no Livro Didático. In MUNANGA, Kabengele (org.) Superando o Racismo na escola. $2^{\text {a }}$ edição revisada /- MEC/SECADI: Brasília, 2005.

SOUZA, F. A. T. de. A Presença do Negro no Pensamento Social Brasileiro. Revista de História da CECIERJ, $1984 . \quad$ Disponível em: <www.educacaopublica.rj.gov.br/biblioteca/historia /0110.html>. Acesso em: 10 de outubro de 2014.

SOUZA, L. C. O Sacrifício do Carneiro. Uma Radiografia da Presença Islâmica em Salvador.
Livro-Reportagem para a UFBA. Salvador, 2004.

VERGER, P. Crianças: olhar a África e ver o Brasil. Companhia Editora Nacional, 2005.

VILLAR, V. L. G. Os Árabes e Nós: A presença árabe na literatura brasileira. Tese de Doutorado, UFPB, João Pessoa, 2012.

\section{Páginas da Web Consultadas:}

A Mensagem. Disponível em: $<$ https://www.youtube.com/watch?v=hvCz10h4EC A>. Acesso em: 02 de outubro de 2014.

A Presença do Negro no Pensamento Social Brasileiro. Disponível em: $<$ www.educacaopublica.rj.gov.br/biblioteca/historia /0110.html>. Acesso em: 10 de outubro de 2014.

A Queda de Granada. Disponível em: $<$ https://ummahbrasil.com/wp/artigos/historia-doislam/a-queda-de-granada/ $>$. Acesso em: 22 de outubro de 2014.

A visão Islâmica da Escravidão. Disponível em: $<$ http://en.wikipedia.org/wiki/Islamic_views_on_sla very>. Acesso em: 22 de outubro de 2014.

Biblioteca da Casa das Áfricas. Disponível em: <http://www.casadasafricas.org.br/>. Acesso em: 06 de outubro de 2014.

Centro de Estudos Afro-Asiáticos da Universidade Candido Mendes. Disponível em: $<$ http://www.ucam.edu.br/index.php/centro-deestudos-afro-asiaticos $>$. Acesso em: 03 de outubro de 2014.

Centro de Estudos Afro-Orientais da Universidade Federal da Bahia. Disponível em: <http://www.ceao.ufba.br/> Acesso em: 06 de outubro de 2014.

Grandes Cientistas Muçulmanos. Disponível em: $<$ http://www.islam.org.br/grandes_cientistas_mucul manos.htm>. Acesso em: 22 de outubro de 2014.

Herança Muçulmana. Disponível em: <http://www.muslimheritage.com/>. Acesso em: 22 de outubro de 2014.

História da Presença Islâmica no Brasil. Disponível 
em: <http://www.masnavi.org/jerrahi/Artigos__ $\mathrm{Pa}$ lestras/Historia_da_presenca_Islamica_/historia_da _presenca_islamica_html>. Acesso em: $13 \mathrm{de}$ outubro de 2014.

História Geral da África. Disponível em: < http://www.unesco.org/new/pt/brasilia/about-this-of fice/single-view/news/general_history_of_africa_co llection_in_portuguese-1/\#.VEBrh1dGXfw.

História da Presença islâmica no Brasil por Muhammad Regip al-Jerrahi. Disponível em: <www.masvani.org>. Acesso em: 17 de outubro de 2014.

$O$ Filho de Luíza. Disponível em: <http://ofilhodeluisa.blogspot.com.br/> Acesso em: 15 de outubro de 2014.

$O$ Néctar Selado. Disponível em: $\quad<$ http://www.islambr.com.br/index.php?option=com docman\&task=doc_details\&gid=92\&Itemid=125> . Acesso em: 16 de outubro de 2014.

O Último Sermão do profeta Muhammad. Disponível em: <http://www.islamreligion.com/pt/articles/523/ $>$ Acesso em: 14 de outubro de 2014.

Os Documentos Árabes do Arquivo do Estado da
Bahia. Disponível em: <http://www.afroasia.ufba.br/pdf/afroasia_n2_3_p1 69.pdf >. Acesso em: 08 de outubro de 2014.

Profetas do Islam. Disponível em: $<$ http://www.islam.org.br/profetas.htm>. Acesso em: 08 de outubro de 2014.

Resistência de Zumbi dos Palmares. $<$ http://blog.narajr.net/2009/11/resistencia-dezumbi-dos-palmares.html>. Acesso em: 22 de outubro de 2014.

Revista Afro-Ásia da Universidade Federal da Bahia. Disponível em: <http://www.afroasia.ufba.br/>. Acesso em: 06 de outubro de 2014.

Revista de Estudo Afro-Asiáticos da Universidade Candido Mendes. Disponível em: $<$ http://www.scielo.br/scielo.php?script=sci_serial\& lng=en \&pid $=0101-546 \mathrm{X} \% 20 \% 20 \% 20>$. Acesso em: 06 de outubro de 2014.

Visões de Muhammad sobre a escravidão. Disponível em: $<$ http://en.wikipedia.org/wiki/Muhammad\%27s_vie ws_on_slavery>. Acesso em: 22 de outubro de 2014.

\section{Sobre os autores}

Vilma Aparecida de Pinho: Fez mestrado em Educação na UFMT (2004), e doutorado em Educação no Programa de Pós-Graduação da Universidade Federal Fluminense - UFF (2010) e Pós-Doutorado em Educação Física no PPGEF- (2015). É coordenadora do Grupo de Estudos e Pesquisas Afro-brasileiros e Física no PPGEF- (2015). É coordenadora do Grupo de Estudos e Pesquisas Afro-brasileiros e Indígenas/GEABI/UFPA e pesquisa sobre Relações étnico-raciais e Educação; Infância, Diversidade e Direitos Humanos; Corpo e Cultura.

Léia Gonçalves de Freitas: Mestra em Educação, Linguagens e Tecnologias pela Universidade Estadual de Goiás (UEG, 2014). Doutoranda em Educação no Programa de Pós-Graduação da Universidade Federal do Pará. Pesquisa sobre Infância e diversidade.

Maurício Neubson Medeiros Gonçalves: Possui graduação em Pedagogia e Especialização em Educação, Diversidade e Sociedade pela Universidade Federal do Pará. É pesquisador associado no GEABI -Grupo de Estudos e Pesquisas Afro-brasileiros e Indígenas onde pesquisa Capoeira e Pedagogia; Relações étnico-raciais e Educação, Ciências da religião com ênfase nos em estudos Islâmicos.

Valter Luciano Gonçalves Villar: Mestre e Doutor em Literatura e Cultura pela UFPA Universidade Federal da Paraíba. Possui experiência na área de Letras, com ênfase em Literatura, atuando principalmente no seguinte tema: literatura, história e memória cultural. 
Recebido em julho de 2015.

Aprovado em abril de 2016. 